\title{
HUBUNGAN TINGKAT KECUKUPAN ENERGI, PROTEIN DAN INDEKS MASSA TUBUH (IMT) DENGAN POWER ATLET BELADIRI
}

\author{
Relationship between Energy, Protein Adequacy Level and Body Mass Index (BMI) with Martial \\ Art Athletes's Power
}

\author{
Laila Maulida Hidayah ${ }^{1}$, Lailatul Muniroh ${ }^{2}$ \\ ${ }^{1}$ Program Studi S1 Kesehatan Masyarakat, Fakultas Kesehatan Masyarakat, Universitas Airlangga, Surabaya \\ ${ }^{2}$ Departemen Gizi Kesehatan, Fakultas Kesehatan Masyarakat, Universitas Airlangga, Surabaya \\ E-mail:lailamaulid4@gmail.com
}

\begin{abstract}
ABSTRAK
Atlet membutuhkan energi dan protein lebih besar dibanding orang dengan aktivitas normal untuk menyeimbangkan laju metabolik tubuh. Indeks massa tubuh merupakan faktor yang berperan terhadap performa fisik atlet bela diri. Tujuan penelitian ini adalah untuk menganalisis hubungan antara tingkat kecukupan energi, protein dan indeks massa tubuh dengan power atlet bela diri. Penelitian ini merupakan penelitian observasional analitik dengan desain studi cross sectional. Sampel penelitian sebesar 46 orang dan pernah memenangkan minimal satu pertandingan bela diri. Pengambilan data melalui wawancara karakteristik, tingkat kecukupan energi dan protein diukur dengan kuesioner $2 \times 24$ jam food recall, berat badan dan tinggi badan diukur menggunakan digital scale dan microtoice, sedangkan power diukur dengan vertical jump-test. Terdapat hubungan positif antara tingkat kecukupan protein $(\mathrm{p}=0,011)$ dan hubungan negatif antara IMT dengan power atlet $(p=0,019)$ dengan power atlet bela diri. Tidak terdapat hubungan antara tingkat kecukupan energi dengan power atlet bela diri. Penelitian ini dapat disimpulkan bahwa semakin adekuat tingkat kecukupan protein maka power atlet semakin bertambah, semakin bertambahnya nilai IMT maka power akan berkurang. Oleh karena itu perlu adanya pemantauan asupan zat gizi dan IMT agar power atlet dapat meningkat.
\end{abstract}

Kata kunci: atlet bela diri, indeks massa tubuh, kecukupan energi, kecukupan protein, power

\begin{abstract}
Athletes require greater energy and protein than people with normal activity to balance the body's metabolic rate. The body mass index is a factor which directly related to the physical performance of martial-art athletes. The objective of this study was to analyze the relationship between energy, protein sufficiency and body mass index with power of martial-art athletes. This research was observational analytic with cross sectional study design. Samples were consisted of 46 athletes who has won at least one martial art games. Data were collected through interview. Energy and protein adequacy level were measured by $2 \times 24$ hours food recall questionnaires; body weight and height measured by digital scale and microtoice; and power was measured with vertical jump test. There was a positive relationship between adequacy level of protein $(p=0.011)$ and athletes's power, but negative correlation between BMI and athlethes's power $(p=0.019)$. There was no relationship between the adequacy level of energy with power of martial-art athletes. It was concluded that increament of protein adequacy level could increase athlete's power. Otherwise, escalation of body mass index could decrease the power of athletes. Therefore, it is needed to monitor nutrient intake and BMI to increase the power of martial-art athletes.
\end{abstract}

Keywords: martial-art athletes, body mass index, energy adequacy, protein adequacy, power

\section{PENDAHULUAN}

Power merupakan rangkaian kerja dari beberapa unsur gerak otot yang apabila saling bekerja bersamaan akan menghasilkan daya eksplosif yang kuat (Widiastusi, 2015). Pada olahraga yang melibatkan power, beberapa atlet berusaha untuk mendapatkan power mutlak dengan menurunkan massa lemak tubuh. Disisi lain ada cabang olahraga yang harus menggerakkan massa tubuh atlet saat bertanding, maka power yang digunakan bukanlah power mutlak. Dalam olahraga yang menggunakan kategori berat 
badan seperti beladiri biasanya menargetkan lawan yang memiliki berat badan lebih rendah agar dapat memberikan power lebih baik dengan memanfaatkan masa otot yang lebih besar (Abidin dan Adam, 2013).

Faktor utama yang dapat memberikan pengaruh besar terhadap performa power atlet adalah dengan proses latihan. Penelitian yang dilakukan oleh Dhewangga (2015) menyebutkan bahwa penambahan intensitas latihan dapat meningkatkan power atlet. Akan tetapi proses latihan juga harus ditunjang dengan pengaturan zat gizi yang baik. Strategi pengaturan gizi bagi atlet dapat dilakukan sebelum, selama dan setelah latihan. Pengaturan zat gizi sebelum latihan digunakan untuk mengatur berat badan atlet, pengaturan zat gizi selama proses latihan berfungsi untuk menurunkan kelelahan (fatigue) dan cidera, sedangkan pengaturan zat gizi setelah latihan berfungsi untuk recovery (Thomas, et al., 2016).

Atlet beladiri membutuhkan kecukupan energi yang baik khususnya saat proses latihan agar dapat memberikan power maksimal. Herbold dan Eldestein (2012) menyebutkan bahwa kebutuhan energi pada atlet meningkat $30 \%$ hingga dua kali lipat yaitu 3000-6000 untuk laki-laki dan 2500-4000 untuk wanita. Sedangkan kebutuhan protein untuk atlet sekitar 1,2-1,7 g/kgBB/hari (Rodriguez, dkk., 2009).

Pengaturan berat badan pada atlet beladiri menjadi sangat penting karena sistem pertandingan dikategorikan berdasarkan jenis kelamin dan berat badan (Arif, 2007). Di sisi lain dengan adanya pengaturan tersebut, maka setiap atlet seringkali mengesampingkan faktor Indeks Massa Tubuh (IMT). Penelitian Welis, dkk. (2012) menemukan adanya hubungan antara kenaikan nilai indeks massa tubuh (IMT) dengan penurunan performa atlet. Rata-rata atlet Taekwondo yang menjadi juara pada kejuaraan Olimpic Games tahun 2000-2010 memiliki ukuran tinggi badan lebih besar dan IMT yang lebih rendah dibandingkan atlet yang tidak mendapatkan juara (Kazemi, et al., 2013). Oleh karena itu, perlu adanya pembuktian lagi mengenai hubungan IMT dengan prestasi atlet.

Unit Kegiatan Mahasiswa (UKM) Divisi Beladiri Universitas Airlangga selalu menyumbangkan prestasi tiap tahunnya. Pada periode tahun 2013 divisi beladiri menyumbang sebanyak $27 \%$ dari total prestasi mahasiswa, pada periode 2014 sumbangan prestasi meningkat hingga $63 \%$, namun pada periode tahun 2015 sumbangan prestasi hanya $35 \%$ dari seluruh prestasi mahasiswa baik dalam tingkat regional, nasional dan internasional (Informasi Kemahasiswaaan Universitas Airlangga, 2015). Berdasarkan data tersebut, peneliti ingin mencari tahu apakah ada hubungan antara tingkat kecukupan energi, protein dan IMT terhadap power atlet beladiri Universitas Airlangga.

\section{METODE PENELITIAN}

Penelitian ini merupakan penelitian observasional analitik dengan desain studi cross sectional. Populasi dalam penelitian ini adalah atlet Unit Kegiatan Mahasiswa Divisi Beladiri Universitas Airlangga Kriteria inklusi sampel yaitu pernah mendapatkan medali minimal 1 kali yaitu sebanyak 80 orang. Sampel penelitian merupakan atlet beladiri yang termasuk dalam kriteria populasi dan bersedia menjadi responden. Teknik pengambilan sampel menggunakan simple random sampling diperoleh hasil sejumlah 46 atlet. Pengumpulan data dilakukan pada Bulan Oktober sampai dengan Bulan November 2016.

Penelitian ini telah mendapatkan persetujuan dari Komisi Etik Fakultas Kesehatan Masyarakat Universitas Airlangga Surabaya nomor 562-KEPK. Pengumpulan data dilakukan dengan wawancara dan pengukuran secara langsung. Wawancara meliputi karakteristik atlet dan besar asupan zat gizi makro yang diukur menggunakan kuesioner $2 \times 24$ jam food recall. Pengukuran berat dan tinggi badan menggunakan microtoice dan digital scale, sedangkan power diukur dengan vertical jump test. Hasil perhitungan asupan energi dan protein kemudian dikelompokkan berdasarkan kategori tingkat kecukupan menurut Kementrian Kesehatan (2016) yaitu terkategori sangat kurang $\leq 70 \%$ AKE, kurang $(70-<100 \%$ AKE), normal (100-130\% AKE) dan lebih apabila $>130 \%$ AKE). Skor IMT kemudian dikategorikan berdasarkan WHO (2004) yaitu terkategori sangat kurus apabila 
$<$ 17,00 IMT, kurus (17,0-18,4 IMT), normal (18,5-25,0 IMT), overweight (25,1-29,9 IMT) dan obese apabila $\geq 30,00$ IMT. Power atlet dikategorikan berdasarkan performance evaluation test menurut Mackenzie (2005) yaitu di bawah ratarata apabila hasil vertical-jump $\leq 39 \mathrm{~cm}$, rata-rata $(40-49 \mathrm{~cm})$ dan di atas rata-rata apabila $\geq 50 \mathrm{~cm}$. Hubungan antar variabel dianalisis menggunakan uji korelasi Spearman dengan $\alpha=0,005$.

\section{HASIL DAN PEMBAHASAN}

\section{Karakteristik Atlet}

Karakteristik atlet terdiri dari jenis kelamin, umur dan tempat tinggal atlet di Surabaya. Karakteristik atlet dalam penelitian ini dapat dilihat pada Tabel 1.

Tabel 1 menunjukkan bahwa sebagian besar responden adalah atlet laki-laki. Giriwijono dan Santoso (2012) menyatakan bahwa secara fisik atlet laki-laki mempunyai tubuh yang lebih kuat daripada perempuan karena adanya hormon testosteron. Oleh karena itu dalam penelitian lebih banyak ditemukan atlet laki-laki daripada atlet perempuan. Umur atlet yang mengikuti kejuaraan sebagian besar berada pada usia $\leq 20$ tahun. Sebagian besar atlet yang menjadi responden bukan berasal dari Surabaya dan bertempat tinggal di kos atau kontrakan. Pada wawancara food recall ditemukan bahwa atlet yang berasal Surabaya memiliki ragam makanan yang lebih bervariasi.

\section{Tingkat Kecukupan Energi dan Protein}

Tingkat kecukupan energi atlet bela diri dibandingkan dengan standar kecukupan energi menurut Kemenkes (2016). Perhitungan kebutuhan energi dihitung dengan dasar 3 komponen yaitu

Tabel 1. Karakteristik Atlet

\begin{tabular}{lcc}
\hline \multicolumn{1}{c}{ Variabel } & Jumlah & Persentase (\%) \\
\hline Jenis Kelamin & & \\
$\quad$ Laki-laki & 31 & 67,4 \\
$\quad$ Perempuan & 15 & 32,6 \\
Umur & & \\
$\quad \leq 20$ tahun & 28 & 60,9 \\
$\quad>20$ tahun & 18 & 39,1 \\
Asal Daerah & & \\
$\quad$ Surabaya & 18 & 39,1 \\
$\quad$ Non Surabaya & 28 & 60,9 \\
\hline
\end{tabular}

energi Basal Metabolic Rate (BMR), Spesific Dynamic Action (SDA), dan Energi Expenditure untuk setiap jenis dan lama latihan. Atlet bela diri dengan umur antara 18-29 tahun memiliki rumus $\mathrm{BMR}=(15,3 \mathrm{x}$ berat badan $)+679$ untuk atlet lakilaki dan $\mathrm{BMR}=(14,7 \mathrm{x}$ berat badan $)+496$ untuk atlet perempuan (WHO, 2004). Nilai SDA untuk mencerna zat gizi adalah $10 \%$ dari nilai BMR. Selain sebagai atlet, aktivitas fisik responden adalah sebagai mahasiswa sehingga peneliti mengkategorikan aktivitas fisik termasuk kategori sedang dengan standar perhitungan $1,4 \leq x<1,6$. Energi expenditure ditentukan oleh jenis olahraga, intensitas dan lama latihan fisik (Kemenkes, 2014). Setelah itu tingkat kecukupan zat gizi atlet dikategorikan berdasarkan klasifikasi menurut Kemenkes (2016) dimana tingkat kecukupan energi atlet $95,7 \%$ terkategori sangat kurang dan 4,3\% terkategori kurang. Sedangkan tingkat kecukupan protein atlet $71,7 \%$ sangat kurang, $23,9 \%$ kurang dan hanya 4,3\% yang memiliki kecukupan protein normal. Rata-rata asupan energi atlet adalah $1390,4 \pm 520$ kalori, sedangkan rata-rata asupan protein adalah $50,4 \pm 22,7 \mathrm{~g}$.

\section{Indeks Massa Tubuh (IMT)}

Indeks massa tubuh atlet menunjukkan nilai rata-rata $21,9 \pm 2,8 \mathrm{~kg} / \mathrm{m}^{2}$ dengan IMT minimal $17,1 \mathrm{~kg} / \mathrm{m}^{2}$ dan maksimal $31,7 \mathrm{~kg} / \mathrm{m}^{2}$. Berdasarkan klasifikasi menurut WHO (2004), sebanyak 80,4\% atlet terkategori kurus dan ada 2,2\% atlet yang terkategori obesitas. Nilai IMT merupakan rasio untuk membandingkan berat badan terhadap tinggi badan (Adiningsih, dkk., 2016), sehingga dapat diketahui apakah berat badan atlet sudah ideal dibandingkan dengan tinggi badannya. Persentase Indeks Massa Tubuh Atlet dapat dilihat pada Tabel 2.

Tabel 2. Presentase Indeks Massa Tubuh Atlet

\begin{tabular}{lrr}
\hline \multirow{2}{*}{ Klasifikasi IMT } & \multicolumn{2}{c}{ Jumlah } \\
\cline { 2 - 3 } & n & \% \\
\hline Sangat Kurus & 3 & 6,5 \\
Kurus & 37 & 80,4 \\
Normal & 3 & 6,5 \\
Overweight & 2 & 4,3 \\
Obese & 1 & 2,2 \\
Total & 46 & 100,0 \\
\hline
\end{tabular}




\section{Power Atlet}

Sebagian besar power atlet laki-laki terkategori di bawah rata-rata dengan nilai rata-rata 45,8 $\mathrm{cm}$. Sebagian power atlet perempuan berada di bawah rata-rata dengan skor $27,1 \mathrm{~cm}$. Power yang baik pada atlet bela diri akan membuat serangan semakin keras sehingga lawan akan sulit untuk menangkis serangan (Widiastuti, 2015).

\section{Hubungan Tingkat Kecukupan Energi dengan Power Atlet}

Tabel 3 menunjukkan bahwa sebagian besar atlet dengan tingkat kecukupan energi sangat kurang memiliki power di bawah rata-rata yaitu $61,4 \%$ sedangkan atlet dengan tingkat kecukupan energi kurang memiliki power diatas rata-rata dan di bawah rata-rata. Uji korelasi Spearman antara tingkat kecukupan energi dengan power atlet bela diri Universitas Airlangga menunjukkan hasil signifikansi yang lebih dari $0,05(\mathrm{p}=0,604)$ artinya tidak terdapat hubungan antara tingkat kecukupan energi dengan power atlet bela diri Universitas Airlangga. Kondisi ini dapat disebabkan karena persebaran data tidak merata.

\section{Hubungan Tingkat Kecukupan Protein dengan Power Atlet}

Tabel 3 menunjukkan bahwa sebagian besar atlet yang memiliki tingkat kecukupan protein sangat kurang memiliki power di bawah ratarata, sebagian besar atlet yang memiliki tingkat kecukupan protein kurang memiliki power di atas rata-rata dan atlet yang memiliki tingkat kecukupan protein normal memiliki power rata-rata dan diatas rata-rata. Uji korelasi Spearman antara tingkat kecukupan protein dengan performa fisik power atlet diperoleh hasil yang signifikan ( $p=0,011$ dan $r=0,372)$. Hal ini berarti bahwa terdapat koreasi positif antara tingkat kecukupan protein dengan power atlet UKM divisi bela diri Universitas Airlangga.

Penelitan ini sejalan dengan penelitian yang dilakukan oleh Sumida, et al. (2012) yang menemukan hubungan positif antara tingkat kecukupan protein dengan power otot atlet Shorinji Kempo di Jepang. Penelitian tersebut juga menyatakan bahwa protein merupakan zat gizi penting yang berperan pada proses pemulihan akibat kerusakan otot yang timbul karena adanya hipertrofi sehingga dapat berkontribusi untuk meningkatkan performa atlet.

Harahap (2014) dalam penelitiannya menyatakan bahwa proses latihan selama tiga kali dalam seminggu terbukti dapat menurunkan konsentrasi glutamin yang dapat menekan fungsi kekebalan tubuh walaupun sudah mengkonsumsi diet yang sehat. Penelitian Harahap juga menyebutkan bahwa penambahan 20 gram protein pada diet harian mampu meningkatkan power atlet

Tabel 3. Distribusi Silang Tingkat Kecukupan Energi, Protein dan IMT dengan Power Atlet Beladiri Universitas Airlangga Tahun 2016

\begin{tabular}{|c|c|c|c|c|c|c|c|c|c|c|}
\hline \multirow{3}{*}{ Variabel } & \multirow{3}{*}{ Klasifikasi } & \multicolumn{6}{|c|}{ Power Atlet } & \multirow{2}{*}{\multicolumn{2}{|c|}{ Total }} & \multirow{3}{*}{ p value } \\
\hline & & \multicolumn{2}{|c|}{ Dibawah Rata-rata } & \multicolumn{2}{|c|}{ Rata-rata } & \multicolumn{2}{|c|}{ Diatas Rata-rata } & & & \\
\hline & & $\mathbf{n}$ & $\%$ & $\mathbf{n}$ & $\%$ & $\mathbf{n}$ & $\%$ & $\mathbf{n}$ & $\%$ & \\
\hline \multirow[t]{4}{*}{ Energi } & Sangat kurang & 27 & 61,4 & 7 & 15,9 & 10 & 22,7 & 44 & 100 & \multirow{4}{*}{0,604} \\
\hline & Kurang & 1 & 50,0 & 0 & 0,0 & 1 & 50,0 & 2 & 100 & \\
\hline & Normal & 0 & 0,0 & 0 & 0,0 & 0 & 0,0 & 0 & 0 & \\
\hline & Lebih & 0 & 0,0 & 0 & 0,0 & 0 & 0,0 & 0 & 0 & \\
\hline \multirow[t]{4}{*}{ Protein } & Sangat kurang & 23 & 69,7 & 6 & 18,2 & 4 & 12,1 & 33 & 100 & \multirow{4}{*}{0,011} \\
\hline & Kurang & 5 & 45,5 & 0 & 54,5 & 6 & 54,5 & 11 & 100 & \\
\hline & Normal & 0 & 0,0 & 1 & 50,0 & 1 & 50,0 & 2 & 100 & \\
\hline & Lebih & 0 & 0,0 & 0 & 0,0 & 0 & 0,0 & 0 & 0 & \\
\hline \multirow[t]{5}{*}{ IMT } & Sangat kurus & 1 & 33,3 & 0 & 0,0 & 2 & 66,7 & 3 & 100 & \multirow{5}{*}{0,019} \\
\hline & Kurus & 21 & 56,8 & 7 & 18,9 & 9 & 24,3 & 37 & 100 & \\
\hline & Normal & 3 & 100,0 & 0 & 0,0 & 0 & 0,0 & 3 & 100 & \\
\hline & Overweight & 2 & 100,0 & 0 & 0,0 & 0 & 0,0 & 2 & 100 & \\
\hline & Obese & 1 & 100,0 & 0 & 0,0 & 0 & 0,0 & 1 & 100 & \\
\hline
\end{tabular}


lari. Hal tersebut dikarenakan hampir sepertiga profil asam amino dalam protein digunakan untuk sintesa glutamin dalam otot.

Protein merupakan zat gizi makro sebagai sumber asam amino esensial dalam tubuh. Sebanyak $80 \%$ dari total asam amino bebas yang ada di dalam tubuh berada di jaringan otot. Dalam jaringan otot, asam amino akan mengalami oksidasi untuk memproduksi ATP sehingga cukup memenuhi kebutuhan energi (Poortmans, et al., 2012)

\section{Hubungan IMT dengan Power Atlet}

Tabel 3 menunjukkan bahwa atlet yang memiliki kategori IMT kurus 55\% memiliki kategori power di bawah rata-rata dan $40 \%$ di atas rata-rata. Sebagian besar atlet dengan IMT normal dan overweight memiliki kategori power di bawah rata-rata. Tabel Uji korelasi Spearman antara IMT dengan power atlet bela diri diperoleh hasil $\mathrm{p}=0,019$ dan $\mathrm{r}=-0,344$ artinya terdapat hubungan negatif antara IMT dengan power atlet UKM divisi bela diri Universitas Airlangga. Nilai IMT yang tinggi terjadi karena BB melebihi standar normal. Hal ini menunjukkan ada beban yang lebih pada orang yang memiliki berat badan lebih tinggi pada orang dengan tinggi badan yang sama. Oleh karena itu atlet dengan IMT lebih besar memiliki power yang rendah. Penelitian ini sejalan dengan penelitian Welis, dkk. (2012) yang menyatakan bahwa adanya korelasi negatif antara IMT dengan performa fisik atlet.

\section{KESIMPULAN DAN SARAN}

Penelitian ini menunjukkan semakin adekuat tingkat kecukupan protein dan semakin normal IMT atlet maka semakin meningkatkan power atlet. Oleh karena itu setiap UKM bela diri perlu memantau asupan zat gizi atlet khususnya protein serta IMT atlet agar dapat meningkatkan power atlet bela diri.

\section{DAFTAR PUSTAKA}

Abidin, N.Z., \& Adam, M.B. (2013). Prediction of vertical jump height from anthropometric factors in male and female martial arts athletes. Malaysia Journal of Medical Science, 20(1), 39-45.

Adiningsih, S., Muniroh, L., Nadhiroh, S.R., Nindya, T.S., \& Andrias, D.R. (2014). Buku panduan praktikum gizi. Surabaya: Departemen Gizi Masyarakat Fakultas Kesehatan Masyarakat Universitas Airlangga (Hanya untuk kalangan sendiri)

Arif, G.G. (2007). Beladiri. Jakarta: Graha Ilmu.

Dhewangga, W. (2015). Pengaruh intensitas latihan dengan kekuatan kardiorespirasi atlet futsal (Skripsi, Universitas Muhammadiyah, Surakarta, Surakarta). Diakses dari eprints.ums. ac.id/32839/12/NASKAH\%20PUBLIKASI. pdf

Giriwijono, H.Y.S., \& Santoso, D.Z.S. (2012). Ilmu kesehatan olahraga. Bandung: PT Remaja Rosdakarya.

Harahap, N.S. (2014). Protein dalam nutrisi olahraga. Jurnal Ilmu Kesehatan, 13(2), 4554.

Herbold, N., \& Edelstein, S. (2012). Buku saku nutrisi. Jakarta: Penerbit Buku Kedokteran (EGC).

Informasi Kemahasiswaaan Universitas Airlangga. (2015). Data prestasi mahasiswa Universitas Airlangga. Surabaya: Airlangga University Press.

Kazemi, M., De Ciantis, M.G., \& Rahman, A.A. (2013). A profile of the youth olimpic taekwondo athlete. J Can Chiropr Assoc, 57(1), 293-300.

Kementrian Kesehatan Republik Indonesia (2014). Pedoman gizi olahraga prestasi. Jakarta: Kemenkes RI.

Kementrian Kesehatan Republik Indonesia (2016). Situasi gizi di Indonesia. Jakarta: Kemenkes RI.

Mackenzie. (2005). 101 performance evaluation test. London: Electric World plc.

Poortmans, J.R., Carpentier, A., Pereira-Lancha, L.O., \& Lancha, J. (2012). Protein turnover, amino acid requirements and recommendations 
for athletes and active population. Brazilian Journal of Medical and Biological Research, 45(10), 875-890.

Rodriguez, Marco, D.N.M., Langley, S. (2009). Nutrition \& athletic performance. Journal of the American Dietetic Association, 01 (005), 509-527.

Sumida, S., Iwamoto, J., Kamide, N., \& Otani, T. (2012). Evaluation of bone, nutrition, and physical function in Shorinji Kempo Athletes. Jurnal of Sport Medicine, 2(7), 107-114.

Thomas, D.T., Erdman, K.A., \& Burke, L.M. (2016). Nutrition and athletic performance.
American College of Sport Medecine, 852(10), 543-568.

Welis, W., Rimbawan, Sulaiman, A., \& Riyadi, H. (2012). Hubungan hemoglobin, IMT, lemak tubuh dan $\mathrm{VO}_{2 \text { maks }}$ dengan performa lari $5 \mathrm{~km}$. Media Gizi Indonesia, 2(9), 1528-1538.

Widiastuti. (2015). Tes dan pengukuran olahraga. Jakarta: PT Raja Grafindo Persada.

World Health Organization. (2004). Appropriate body-mass index for asian population and its implications for policy and intervention strategies. The Lancet, 363(10), 158-163. 